\title{
Effect of Previous Crops and Fertilizers Management of Stem Amaranth in Vegetables - Vegetables - Rice Cropping System
}

\section{Shila Pramanik ${ }^{1^{*}}$, Mohammad Zakaria ${ }^{2}$, Mohammad Mofazzal Hossain ${ }^{2}$, Mohammad Moynul Haque ${ }^{3}$ and Mohammad Abu Saleque ${ }^{4}$}

\footnotetext{
${ }^{1}$ Department of Rice farming systems, Bangladesh Rice Research Institute, Gazipur, Bangladesh. ${ }^{2}$ Department of Horticulture, Bangabandhu Sheikh Mujibur Rahman Agricultural University, Gazipur, Bangladesh.
${ }^{3}$ Department of Agronomy, Bangabandhu Sheikh Mujibur Rahman Agricultural University, Gazipur, ${ }^{4}$ Department of Soil Science, Bangladesh Rice Research Institute, Gazipur, Bangladesh.
}

Authors' contributions

This work was carried out in collaboration among all authors. Authors SP and MZ designed the conceptual framework of study, performed relevant literature search and wrote the initial draft of the manuscript. Author MAS drawn the pictures and assisted in the formulation of tabular constituents. Authors M. M. Hossain and M. M. Haque reviewed and rewrote the manuscript. All authors read and approved the final manuscript.

Article Information

DOI: $10.9734 / A R R B / 2021 / v 36 i 330357$ Editor(s):

(1) Dr. Bechan Sharma, University of Allahabad, India. Reviewers:

(1) Caifang Zhang, Fujian Agriculture and Forestry University, China. (2) A. Ranganadha Reddy, VFSTR Deemed to be University, India Complete Peer review History: http://www.sdiarticle4.com/review-history/67482

Original Research Article

Received 05 February 2021

Accepted 13 April 2021

Published 20 April 2021

\section{ABSTRACT}

Aims: To determine the effect of previous crops and fertilizers management on yield and yield parameters of stem amaranth (Amaranthus tricolor L.) in vegetables-vegetables-rice cropping system.

Study Design: A randomized complete block design (RCBD) with six treatment combinations having four replications was used for the experiment.

Place and Duration of Study: The field experiment was conducted in kharif-1 seasons (April to June) 2018 and 2019 at the research field of Bangabandhu Sheikh Mujibur Rahman Agricultural University, Gazipur, Bangladesh. 


\begin{abstract}
Methodology: The layout was kept undisturbed for the cropping sequence over two years. Factor-A had three previous crops under the cropping system as P1= Potato (Potato - Stem Amaranth - T. Aman rice), P2= Garlic (Garlic - Stem Amaranth $-T$. Aman rice), P3= Cauliflower (Cauliflower - Stem Amaranth - T. Aman rice) and Factor-B had two level of fertilizers management as $F 1=$ Organic fertilizer ( $\mathrm{N}$ based organic compost), F2= Inorganic fertilizer (Estimated inorganic fertilizer dose based on the soil test value without cow dung). The data were recorded on plant height, leaves per plant, stem diameter, stem yield $\left(\mathrm{t} \mathrm{ha}^{-1}\right)$ and stem dry matter content $(\%)$ during harvesting time.

Results: Significantly maximum plant height was observed $(93.5 \mathrm{~cm})$ in inorganic fertilizer treated plot under previous crop cauliflower which was followed by $(93.0 \mathrm{~cm}$ and $75.0 \mathrm{~cm})$ under garlic and potato, respectively. Whereas, minimum plant height $(61.8 \mathrm{~cm})$ receiving organic source of fertilizers when the previous crop was potato in 2019. The interaction of previous crops and fertilizer application showed significant variation on leaves per plant of stem amaranth both in 2018 and 2019. Stem diameter showed the same trend as that of stem dry matter and resulted insignificant influence due to previous crops and fertilizers management over the two years. In 2018, significantly higher stem yield was observed $\left(38 \mathrm{t} \mathrm{ha}^{-1}\right)$ in inorganic fertilizer treated plot under previous crop cauliflower which was followed by $\left(36.1 \mathrm{t} \mathrm{ha}^{-1}\right.$ and $\left.35.5 \mathrm{t} \mathrm{ha}^{-1}\right)$ under garlic and potato, respectively. Whereas, lower stem yield $\left(20.0 \mathrm{t} \mathrm{ha}^{-1}\right)$ receiving inorganic source of fertilizers when the previous crop was cauliflower. Higher stem yield was observed $\left(51.4 \mathrm{t} \mathrm{ha}^{-1}\right)$ in (F2P2) treated plot which was followed by $\left(44 \mathrm{th}^{-1}\right)$ under F2P3 and F2P1, respectively. Whereas, lower stem yield $\left(22.0 \mathrm{t} \mathrm{ha}^{-1}\right)$ receiving F1 source of fertilizers when the previous crop was P3 in 2019.

Conclusion: The experimental results of this study have shown that previous crops had a positive impact on the yield parameters of stem amaranth like plant height in 2018 and leaf numbers of plant both in 2018 and 2019. Interaction effect of previous crops and fertilizers management exerted significant variations only on leaves per plant of amaranth both in 2018 and 2019. Moreover, fertilizers management showed significant variation for plant height in 2019 and for stem yield both in 2018 and 2019. Therefore, it was concluded that stem amaranth after previous crop garlic with soil test based inorganic fertilizer could be high yielding and $\mathrm{N}$ based organic compost could be moderate yielding under Garlic- Amaranth - T. Aman cropping system.
\end{abstract}

Keywords: Previous crops; stem amaranth; organic compost; inorganic fertilizer; yield; yield parameters.

\section{INTRODUCTION}

Stem amaranth (Amaranthus tricolor L.) belongs to the genus Amaranthus of the family Amaranthaceae and is locally known as danta. Amaranth is considered as one of the nutritious and delicious vegetables in Bangladesh because of its cheap price, quick growing character and higher yield potential. It is also, considered as a potential upcoming subsidiary food crop for future generation [1]. The most dominant vegetable cropping pattern is vegetablevegetable - vegetable in Bangladesh covered $1.67 \%$ of net cropped area where as vegetable vegetable - T. Aman is about $1 \%$ of net cropped area of Bangladesh [2]. It is generally grown after rabi crops and after harvesting amaranth, $\mathrm{T}$. Aman is grown easily. Winter rabi crops based rotations for numerous kharif - crops are available under the vegetables - rice based cropping system but little information exists on better preceding rabi crops for (kharif-1) stem amaranth in Bangladesh. There is a serious scarcity of vegetables during the months of May to September. At present amaranth is being cultivated in an area of 10772.47 hectare with a total production of 75146 tons. This average yield is only about $35-40$ tons per hectare [3]. As the nation runs short of vegetables, stem amaranth can play a vital role in the increase of the total vegetable production in the country and it has also scope for export. Fifty-four kinds of different vegetables were exported from Bangladesh and amaranth (Danta) is one of them. The importing countries were mostly in the Middle East. The demand for summer vegetables was found higher than those of winter vegetables [4].

Until recently most of the research work has been mainly confined to the nutrient requirement of an individual crop and fertilizer recommendation made on the basis of fertilizer response data of a single crop without taking into consideration the effect of preceding crop and soil test value. Now it is increasingly realized that when crops are grown in system, the fertilizer needs of an individual crop cannot be precisely determined without taking into account the nature of preceding crop, it's yield level and residual effect of fertilizer application [5]. Amaranth 
requires high soil fertility for rapid growth in a short time. It responds greatly to major essential elements like $\mathrm{N}, \mathrm{P}$ and $\mathrm{K}$ for its growth and yield [6]. Meanwhile, nitrogen is the most crucial input for increasing crop production and has been recognized as the central element for agricultural production. Organic manure is a good source of nutrients, especially $\mathrm{N}, \mathrm{P} \& \mathrm{~S}$ and it's a good means of soil rejuvenation [7]. So, use of OM could be an inevitable practice in the coming years for ensuring sustainable crop productivity without affecting soil fertility [8-9]. As stated by [10], unbalanced use of chemical fertilizers has affected soil health, causing a substantial decrease in soil organic carbon. As a general rule, use of organic fertilizers especially in composted form produces positive effect on soil health and fertility, which consequents increased crop yield on a long-term basis [11].

Several workers stated that application of inorganic fertilizer or organic compost increased yield of stem amaranth. But there is no available research information about the effect of previous rabi crops and fertilizer managements on yield of stem amaranth. Therefore, the objective of this study was to determine the effect of previous crops and fertilizers management on yield and yield parameters of tem amaranth in vegetables - vegetables - rice cropping system.

\section{MATERIALS AND METHODS}

\subsection{Experimental Site and soil}

The field experiment was conducted in kharif-1 seasons (April to June) 2018 and 2019, at the research field of Bangabandhu Sheikh Mujibur Rahman Agricultural University, Gazipur, Bangladesh, located at $24^{\circ} 09^{\prime}$ North Latitude and $90^{\circ} 26^{\prime}$ East Longitude with elevation of $8.2 \mathrm{~m}$ from mean sea level. It belongs to AgroEcological Zone (AEZ-28) as Madhupur Tract. Data on monthly average temperature, relative humidity and rainfall for two years of study are shown in Table 1 and Table 2, respectively. The initial soil chemical properties at $0-15 \mathrm{~cm}$ soil depth had $\mathrm{pH} 6.63$, organic matter content $0.86 \%$, total nitrogen (N) $0.07 \%$, available phosphorus (P) 17 ppm, exchangeable potassium (K) 0.07 Cmol $100 \mathrm{~g}^{-1}$ soil, available sulfur (S) $9 \mathrm{ppm}$, available zinc $(\mathrm{Zn}) 0.8$ ppm and available Boron (B) $0.10 \mathrm{ppm}$.

\subsection{Experimental Design and Treatment}

The experiment was set up in Randomized Complete Block (RCB) design with six treatment combinations having four replications. The unit plot size was $3.5 \mathrm{~m} \times 3.5$ $\mathrm{m}$ for crops having row to row distance $25 \mathrm{~cm}$. The layout was kept undisturbed for the cropping sequence over two years. Factor-A had three previous crops under the cropping system as $\mathrm{P} 1=$ Potato (Potato - Stem Amaranth - T. Aman rice), P2= Garlic (Garlic Stem Amaranth -T. Aman rice), P3= Cauliflower (Cauliflower -Stem Amaranth - T. Aman rice) and Factor-B had two level of fertilizers management as $\mathrm{F} 1=$ Organic fertilizer ( $\mathrm{N}$ based organic compost), $\mathrm{F} 2=$ Inorganic fertilizer (Estimated inorganic fertilizer dose based on the soil test value without cow dung).

\subsection{Experimental Organic Fertilizer}

The test organic fertilizer, $\mathrm{ACl}$ organic compost, used in the experiment was collected from a shop of Agro Chemical Industries $(A C I)$. The chemical composition of the organic compost showed the concentrations of $\mathrm{N}$ as $1.35 \pm 0.5 \%$, $\mathrm{P} 1.8 \pm 0.1 \%$ and $\mathrm{K} 2.1 \pm 0.2 \%$, respectively (Average figure represents analytical results of 10 samples) in dry weight basis. The organic compost was applied as dry weight basis.

\subsection{Previous Crops and test crop}

The previous crops for three cropping system were potato, garlic and cauliflower, respectively. The test crop for all cropping system used in the experiments was a high yielding variety of Stem amaranth (cv. BARI danta-1) released by Bangladesh Agricultural Research Institute, (BARI) and its life cycle is 50 - 60 days (BARI, 2000).

Table 1. Mean monthly minimum and maximum air temperature for the experimental site during stem amaranth growing periods in 2018 and 2019

\begin{tabular}{|c|c|c|c|c|}
\hline \multirow[t]{3}{*}{ Months } & \multicolumn{4}{|c|}{ Mean monthly air temperature $\left({ }^{\circ} \mathrm{C}\right)$} \\
\hline & \multicolumn{2}{|c|}{ Minimum } & \multicolumn{2}{|c|}{ Maximum } \\
\hline & 2018 & 2019 & 2018 & 2019 \\
\hline April & 21.41 & 22.30 & 32.64 & 32.57 \\
\hline May & 22.76 & 25.49 & 31.92 & 34.53 \\
\hline June & 24.78 & 26.20 & 33.56 & 34.00 \\
\hline
\end{tabular}




\subsection{Field experiment}

Sowing and harvest time of previous crops in two growing seasons as shown in Table 3 . The land was prepared very well by deep and cross plowing with a tractor drawn disk and rotavator followed by laddering. The rates of organic and inorganic fertilizers were applied regarding to treatments for test crop as shown in Table 4. Organic compost was calculated based on $\mathrm{N}$ equivalence (117 kg ha ${ }^{-1}$ for amaranth) and applied on dry weight basis two weeks prior to planting. Based on the nutrient (NPKS) properties of initial soil, fertilizers rates were calculated using fertilizer recommendation guide of Bangladesh Agricultural Research Council [12]. For stem amaranth, $1 / 3$ amount of urea and other fertilizers were applied as basal. The rest of urea was applied into two equal splits: $1 / 2$ as $15-$ 20 DAS (Days after seeding) and the rest $1 / 2$ at 40-45 DAS (Days after seeding). Seeds of stem amaranth (var. BARI Data 1) were sown in line with $25 \mathrm{~cm}$ spacing and continuous seeding at a seed rate of $2.25 \mathrm{~kg} / \mathrm{ha}$ during April ,2018-19. Necessary intercultural operations, irrigation, and plant protection measures were done as and when ever required for crop during the period of the experiment.

\subsection{Data Collection and Determination}

The crop was harvested 50 days after seed sowing. The data were recorded on plant height, leaves/plant, stem diameter, stem yield ( $\mathrm{t} \mathrm{ha}{ }^{-1}$ ), stem dry matter content (\%) during harvesting time from ten randomly selected plants in each plot. Plant heights were measured from the surface of the ridge to the apex of the plants and then average height of 10 plants was finally calculated at harvest. Average number of leaves and diameter of stem were recorded from 10 plants. After harvesting, the yield of total stems per $\mathrm{m}^{2}$ per plot were recorded in Kilograms separately and converted into $\mathrm{t} \mathrm{ha}^{-1}$. Stem dry matter content was determined on a composite, fresh sub-sample of stem of approximately $150 \mathrm{~g}$ taken from the different size stems after oven drying at $80 \pm 2{ }^{0} \mathrm{C}$ for 72 hours and was calculated by dividing the dry weight of stems to the fresh weight stems and multiplied by 100 .

\subsection{Analysis of Soil Samples}

Initial soil samples were analyzed for physical and chemical properties following standard methods. Organic matter was determined by Walkley and Black method [13], soil pH (1:2.5 soil-water) by glass electrode $\mathrm{pH}$ meter method [14], total $\mathrm{N}$ by Semi-micro Kjeldahl method [15], available $P$ by Olsen method [16], exchangeable $\mathrm{K}$ by Flame Photometer after extraction with $1 \mathrm{~N}$ $\mathrm{NH}_{4} \mathrm{OAC}$ at $\mathrm{pH} 7.0$ [17], available $\mathrm{S}$ by extracting soil samples with $\mathrm{CaCl}_{2}$, solution $(0.15 \%)$ and by measuring turbidity by Spectrophotometer [18] method.

\subsection{Statistical Analysis}

The data were subjected to statistical analysis by using the software CropStat7.2 version to find out the significance of variation between treatments. The difference between the treatment means were judged by Duncan's Multiple Range Test (DMRT) according to [19].

Table 2. Mean monthly relative humidity and rainfall for the experimental site during stem amaranth growing periods in 2018 and 2019

\begin{tabular}{lllll}
\hline Months & \multicolumn{2}{c}{ Relative humidity (\%) } & \multicolumn{2}{c}{ Rainfall (mm) } \\
\cline { 2 - 5 } & $\mathbf{2 0 1 8}$ & $\mathbf{2 0 1 9}$ & $\mathbf{2 0 1 8}$ & $\mathbf{2 0 1 9}$ \\
April & 76.07 & 80.54 & 1.00 & 3.90 \\
May & 81.28 & 80.82 & 14.50 & 6.23 \\
June & 80.66 & 85.00 & 10.34 & 5.64 \\
\hline
\end{tabular}

Table 3. Sowing and harvest time of previous rabi crops in two growing seasons (2018-2019)

\begin{tabular}{lll}
\hline Previous rabi crops & Sowing time & Harvesting time \\
\hline Potato & $25-30$ November & $1-4$ March \\
Garlic & $14-15$ October & $20-22$ March \\
Cauliflower & $12-15$ September & $25-30$ December \\
\hline
\end{tabular}


Table 4. Rate of fertilizers applied for stem amaranth in vegetables - vegetables - rice cropping system, 2018 - 2019

\begin{tabular}{|c|c|c|c|c|c|c|}
\hline \multicolumn{7}{|c|}{ Nutrient (kg/ha) } \\
\hline Treatment & $\mathbf{N}$ & $\mathbf{P}$ & $\mathbf{K}$ & $\mathbf{S}$ & $\mathbf{Z n}$ & B \\
\hline \multicolumn{7}{|c|}{$\mathrm{CP} 1=$ Potato - Stem Amaranth $-\mathrm{T}$. Aman rice } \\
\hline F1 & 09 & & & & & \\
\hline F2 & 117 & 18 & 60 & 5 & - & - \\
\hline \multicolumn{7}{|c|}{ CP2 $=$ Garlic - Stem Amaranth - T. Aman } \\
\hline F1 & 09 & & & & & \\
\hline F2 & 117 & 18 & 60 & 5 & - & - \\
\hline \multicolumn{7}{|c|}{ CP3 $=$ Cauliflower - Stem Amaranth $-\mathrm{T}$. Aman } \\
\hline F1 & 09 & & & & & \\
\hline F2 & 117 & 18 & 60 & 5 & - & - \\
\hline
\end{tabular}

\section{RESULTS AND DISCUSSION}

\subsection{Plant Height}

Plant height of stem amaranth demonstrated poor interaction effect of previous crops and fertilizer application in the amaranth both in 2018 and 2019. Previous crops had significant effect $(P=.01)$ on plant height of stem amaranth in 2018 but not in 2019 Table 5. In 2018, fertilizer treatments showed no significant difference in amaranth height among all the cropping system in 2018 Fig. 1a. Amaranth produced taller plants $(>80 \mathrm{~cm})$ when the previous crop was garlic in cropping system(CP2) than the plants grown after potato in CP1. Stem height of amaranth was $65 \mathrm{~cm}$ in organic fertilizer treated plot (F1) and $57 \mathrm{~cm}$ in inorganic fertilizer treated plots (F2) where the previous crop was potato in CP Fig. $1 \mathrm{a}$. In 2019, significant difference was observed on plant height between fertilizer treatments among all the previous crops. Maximum plant height was observed $(93.5 \mathrm{~cm})$ in inorganic fertilizer (F2) treated plot under $\mathrm{P} 3$ which was followed by $(93.0 \mathrm{~cm}$ and $75.0 \mathrm{~cm})$ under $\mathrm{F} 2 \mathrm{P} 2$ and $\mathrm{F} 2 \mathrm{P} 1$, respectively. Whereas, minimum plant height $(61.8 \mathrm{~cm})$ receiving $\mathrm{F} 1$ source of fertilizers when the previous crop was P1 Fig. 1b. As a results, plants grew well during the growing period in all of the treatments. However, the plant height ranged from $(61.80$ to 83.50$) \mathrm{cm}$ recorded in $\mathrm{F} 1$ and from (57.00 to 93.50$) \mathrm{cm}$ recorded in F2 for all the pre-crops over the two years indicating the dominant role of soil test based inorganic source of fertilizer on plant growth. More rapid growth of amaranth was realized with use of chemical fertilizer compared to compost. This could be due to increased availability of soil nitrogen with application of inorganic fertilizer culminating into enhanced $\mathrm{N}$ uptake and hence faster growth.
Release of nitrogen by compost however occurs slowly after mineralization. These findings are in agreement with those of other researchers [2022] who found that while nitrogen supplied by inorganic fertilizer was readily available, the nitrogen supplied by manure was released slowly. The plant height in different treatments varied possibly due to applied treatments effect.

\subsection{Leaves Per Plant}

The interaction of previous crops and fertilizer application showed significant effect $(P=.01)$ on leaves per plant of stem amaranth both in 2018 and 2019.Similarly, previous crops had significant effect $(P=.01)$ on leaves per plant of stem amaranth both in 2018 and 2019 Table 6. Significant difference was observed under all the previous crops on amaranth leaves per plant due to fertilizer treatments both in 2018 and 2019 Fig. 2a-b. In 2018, highest leaves per plant was observed (48.0) in inorganic fertilizer (F2) treated plot under P1 which was followed by (31.0 and 25.8) under F2P3 and F2P2, respectively. Whereas, lowest leaves per plant (21.8) receiving F1 source of fertilizers when the previous crop was cauliflower Fig. 2a. Similar trend was observed in leaves per plant due to fertilizer treatment under all the previous crops in 2019 Fig. 2b. The maximum number of leaves per plant was at soil test based inorganic fertilizer because there was fast release of nitrogen and other plant nutrients (phosphorus and potassium) than organic manures and available nitrogen was high at root zone. However, nitrogen initiated higher growth of stem and leaves of plant. Similar result was also found by [23-25] in their research with fertilizers (recommended dose) and manures. 


\subsection{Stem Diameter}

Stem diameter of amaranth demonstrated poor significant effect by previous crops in the amaranth under all the Previous crops both in 2018 and 2019. However, interaction effect of previous crops and fertilizer application was not significant. Similarly, it was observed that stem diameter did not differ significantly due to fertilizer treatments both in 2018 and 2019 Table 7. In 2018, higher stem diameter was observed $(18.5 \mathrm{~mm})$ in inorganic fertilizer $(\mathrm{F} 2)$ treated plot which was followed by $(17.8 \mathrm{~mm})$ under F2P3 and F2P2, respectively. Whereas, lower stem diameter $(13.0 \mathrm{~mm})$ receiving $\mathrm{F} 2$ source of fertilizers when the previous crop was potato Fig. 3a. Similar trend was observed in stem diameter due to fertilizer treatment under all the previous crops in 2019 Fig. 3b. The stem diameter significantly affected by different levels of compost in combination with or without $\mathrm{N}$ fertilizers [26]. The stem diameter in different treatments varied possibly due to applied treatments effect.

\subsection{Stem Dry Matter}

Stem dry matter of amaranth showed insignificant interaction effect of previous crops and fertilizer application in the current amaranth both in 2018 and 2019. However, stem dry matter of amaranth was not affected by the previous crops Table 8 . Similarly, it was observed that stem dry matter did not differ significantly due to fertilizer treatments both in 2018 and 2019 Table 8. In 2018, higher stem dry matter was observed $(11.3 \%)$ in organic fertilizer (F1) treated plot which was followed by $(10.5 \%$ and $10.2 \%$ ) under F2P2 and F2P3, respectively. Whereas, lower stem dry matter $(9.1 \%)$ receiving F2 source of fertilizers when the previous crop was P2 Fig. 4a. Similar trend was observed in stem dry matter due to fertilizer treatment under all the previous crops in 2019 Fig. 4b. Similar result was also found in the previous study of response of fertilizers on yield of Amaranthus types in coastal Karnataka [26]. The stem dry matter in different treatments varied possibly due to applied treatments effect.

Table 5. Plant height $(\mathrm{cm})$ of stem amaranth as affected by previous crops and fertilizers management under vegetables - vegetables - Rice cropping system during kharif-1, 2018 and 2019

\begin{tabular}{|c|c|c|c|c|}
\hline \multirow{2}{*}{ Fertilizer management } & \multicolumn{3}{|c|}{ Previous crops } & \multirow[t]{2}{*}{ Mean } \\
\hline & Potato & Garlic & Cauliflower & \\
\hline \multicolumn{5}{|l|}{2018} \\
\hline F1 & 65.0 & 83.5 & 65.8 & 71.4 \\
\hline F2 & 57.0 & 81.5 & 84.3 & 74.2 \\
\hline Mean & $61.0 \mathrm{~B}$ & $82.5 \mathrm{~A}$ & $75.0 \mathrm{AB}$ & \\
\hline $\mathrm{LSD}_{0.05}$ for Precrop & $12.7^{*}$ & & & \\
\hline LSD $_{0.05}$ for Fertilizer & NS & & & \\
\hline LSD $_{0.05}$ for Precrop x Fertilizer & NS & & & \\
\hline $\mathrm{CV} \%$ & 16.4 & & & \\
\hline \multicolumn{5}{|l|}{2019} \\
\hline F1 & 61.8 & 68.0 & 72.5 & $67.3 \mathrm{~B}$ \\
\hline F2 & 75.5 & 93.0 & 93.5 & $87.2 \mathrm{~A}$ \\
\hline Mean & 68.2 & 80.2 & 83.0 & \\
\hline $\mathrm{LSD}_{0.05}$ for Precrop & NS & & & \\
\hline LSD $_{0.05}$ for Fertilizer & $11.2^{*}$ & & & \\
\hline LSD $_{0.05}$ for Precrop x Fertilizer & NS & & & \\
\hline CV\% & 16.7 & & & \\
\hline
\end{tabular}


Table 6. Leaves per plant of stem amaranth as affected by previous crops and fertilizers management under vegetables - vegetables - Rice cropping system during kharif-1, 2018 and 2019

\begin{tabular}{|c|c|c|c|c|}
\hline \multirow[t]{2}{*}{ Fertilizer Management } & \multicolumn{3}{|c|}{ Previous crops } & \multirow[t]{2}{*}{ Mean } \\
\hline & Potato & Garlic & Cauliflower & \\
\hline \multicolumn{5}{|l|}{2018} \\
\hline F1 & 24.4 & 25.0 & 21.8 & $23.7 \mathrm{~B}$ \\
\hline $\mathrm{F} 2$ & 48.0 & 25.8 & 31.0 & $34.9 \mathrm{~A}$ \\
\hline Mean & $36.2 \mathrm{~A}$ & $25.3 \mathrm{~B}$ & $26.4 \mathrm{~B}$ & \\
\hline $\mathrm{LSD}_{0.05}$ for Precrop & $3.7^{\star}$ & & & \\
\hline $\mathrm{LSD}_{0.05}$ for Fertilizer & $3.0^{*}$ & & & \\
\hline LSD $_{0.05}$ for Precrop x Fertilizer & $5.2^{*}$ & & & \\
\hline CV\% & 11.7 & & & \\
\hline \multicolumn{5}{|l|}{2019} \\
\hline F1 & 22.5 & 23.0 & 20.0 & $21.7 \mathrm{~B}$ \\
\hline F2 & 46.0 & 24.0 & 29.0 & $32.9 \mathrm{~A}$ \\
\hline Mean & $34.2 \mathrm{~A}$ & $23.3 \mathrm{~B}$ & $24.3 \mathrm{~B}$ & \\
\hline $\mathrm{LSD}_{0.05}$ for Precrop & $3.7^{*}$ & & & \\
\hline $\mathrm{LSD}_{0.05}$ for Fertilizer & $2.9^{*}$ & & & \\
\hline LSD $_{0.05}$ for Precrop x Fertilizer & $5.2^{x}$ & & & \\
\hline $\mathrm{CV} \%$ & 12.6 & & & \\
\hline \multicolumn{5}{|c|}{$\begin{array}{c}\text { Mean value of the same category followed by different letters are significantly different from each other at } P= \\
0.05 \text { using } L S D \text { test. }{ }^{*} \text { Significant at } 5 \% \text { level of probability, } N S=\text { not significant, } L S D \text { least significant difference, } \\
C V=\text { coefficient of variation, } F_{1}=\text { Organic fertilizer ( } N \text { based organic compost) and } F_{2}=\text { Inorganic fertilizer } \\
\text { (Estimated inorganic fertilizer dose based on the soil test value without cow dung) }\end{array}$} \\
\hline
\end{tabular}

\begin{tabular}{|c|c|c|c|c|}
\hline \multirow[t]{2}{*}{ Fertilizer Management } & \multicolumn{3}{|c|}{ Previous crops } & \multirow[t]{2}{*}{ Mean } \\
\hline & Potato & Garlic & Cauliflower & \\
\hline \multicolumn{5}{|l|}{2018} \\
\hline F1 & 15.5 & 15.8 & 15.3 & 15.5 \\
\hline $\mathrm{F} 2$ & 13.0 & 17.8 & 18.5 & 16.4 \\
\hline Mean & 14.2 & 16.8 & 16.9 & 15.9 \\
\hline $\mathrm{LSD}_{0.05}$ for Precrop & \multicolumn{4}{|c|}{ NS } \\
\hline $\mathrm{LSD}_{0.05}$ for Fertilizer & \multicolumn{4}{|l|}{ NS } \\
\hline $\mathrm{LSD}_{0.05}$ for Precrop x Fertilizer & \multicolumn{4}{|l|}{ NS } \\
\hline CV\% & \multicolumn{4}{|l|}{16.4} \\
\hline \multicolumn{5}{|l|}{2019} \\
\hline F1 & 17.5 & 14.8 & 16.3 & 17.2 \\
\hline $\mathrm{F} 2$ & 14.0 & 16.8 & 19.8 & 16.9 \\
\hline Mean & 15.7 & 15.8 & 18.1 & 16.5 \\
\hline $\mathrm{LSD}_{0.05}$ for Precrop & NS & & & \\
\hline LSD $_{0.05}$ for Fertilizer & NS & & & \\
\hline $\mathrm{LSD}_{0.05}$ for Precrop x Fertilizer & NS & & & \\
\hline $\mathrm{CV} \%$ & 16.4 & & & \\
\hline
\end{tabular}



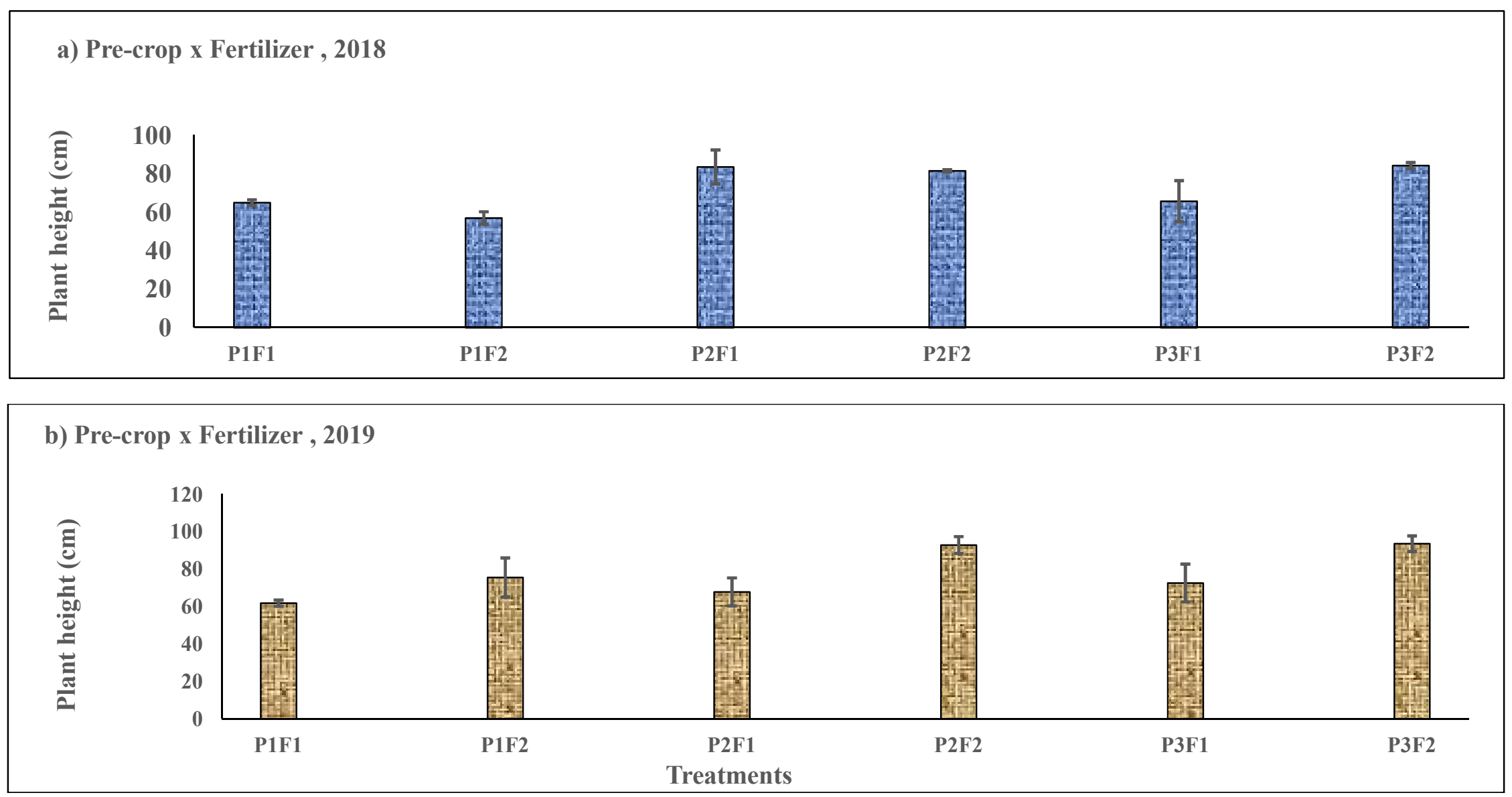

Fig. 1. Effect of the interaction of (a) Pre-crop x Fertilizer, 2018 and (b) Pre-crop x Fertilizer, 2019 on plant height of amaranth. Error bars represent standard error of the mean $(n=4)$. Different lower case letters indicate significant differences between all treatments in each item $(P=0.05)$. $P 1$ : Potato; P2: Garlic; P3: Cauliflower; F1: Organic fertilizer; F2: Inorganic fertilizer 


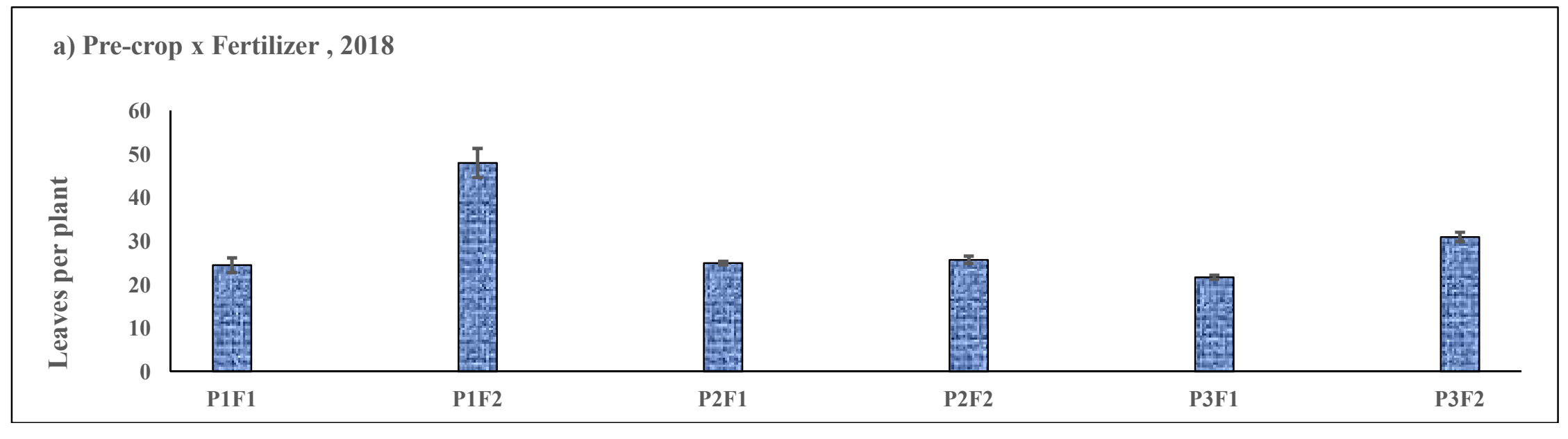

b) Pre-crop x Fertilizer, 2019

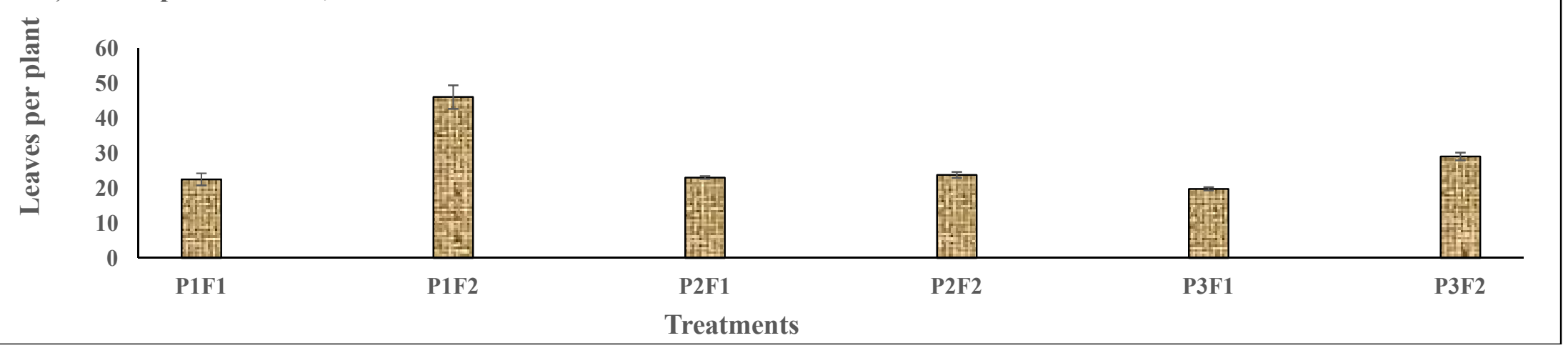

Fig. 2. Effect of the two-way interactions of (a) Pre-crop x Fertilizer, 2018 and (b) Pre-crop x Fertilizer, 2019 on leaves per plant of amaranth. Error bars represent standard error of the mean $(n=4)$. Different lower case letters indicate significant differences between all treatments in each item $(P$ = 0.05). P1: Potato; P2: Garlic; P3: Cauliflower; F1: Organic fertilizer; F2: Inorganic fertilizer 


\subsection{Stem Yield $\left(\mathrm{t} \mathrm{ha}^{-1}\right)$}

The interaction of previous crops and fertilizer application demonstrated insignificant effect on stem yield of amaranth both in 2018 and 2019 . However, stem yield of amaranth was poor significant effect by the previous crops in 2018 and not significant effect in 2019 Table 9. In case of all previous crops, stem yield of amaranth was significantly distinct due to fertilizer application both in 2018 and 2019(Fig.5a-b). In 2018, higher stem yield was observed (38 $\mathrm{t} \mathrm{ha}^{-1}$ ) in (F2P3) treated plot which was followed by $\left(36.1 \mathrm{t} \mathrm{ha}^{-}\right.$ and $35.5 \mathrm{t} \mathrm{ha}^{-1}$ ) under F2P2 and F2P1, respectively. Whereas, lower stem yield $(20.0 \mathrm{t}$ ha $^{-1}$ ) receiving $\mathrm{F} 1$ source of fertilizers when the previous crop was P3 (Fig. 5a). Higher stem yield was observed (51.4 $\mathrm{tha}^{-1}$ ) in (F2P2) treated plot which was followed by (44 $\mathrm{t} \mathrm{ha}^{-1}$ ) under F2P3and F2P1, respectively. Whereas, lower stem yield $\left(22.0 \mathrm{t} \mathrm{ha}^{-1}\right)$ receiving $\mathrm{F} 1$ source of fertilizers when the previous crop was P3 in 2019 (Fig. 4b). Result showed that, the application F1 fertilizer produced higher (>22 $\mathrm{t} \mathrm{ha} \mathrm{ha}^{-1}$ ) stem yield of amaranth in 2019 than (>20 t ha ${ }^{-1}$ ) stem yield in
2018 by all the pre-crops (Fig. 5a-b) due to all the $F 1$ treated plots implying sufficient nitrogen release, coupled with nitrogen carryover from the previous crops, with resultant enhanced uptake and consequently higher crop yields. This is in agreement with the findings of [20-21] who reported that use of manures could help build soil fertility and increase nitrogen supply for the succeeding crops. Proportionate distribution of rainfall and better availability of sunshine hours at growth and maturity stages of amaranth with fertilizers during the cropping season in general and more availability of nutrients under soil test based inorganic fertilizer management treatment achieved higher yield performance in 2019 than in 2018. Similar result was also found by [27-28] in their research with fertilizers and manures where NPK (Recommended dose) fertilizers gave the highest yield for Indian spinach. The cause of this type of results may be because of huge and available nitrogen in recommended dose of fertilizers which facilitated to maintain leafy vegetative growth of Indian spinach. The stem yield in different treatments varied possibly due to applied treatments effect.

Table 8. Stem dry matter (\%) of amaranth as affected by previous crop and fertilizers management under vegetables - vegetables - Rice cropping system during kharif-1, 2018 and 2019

\begin{tabular}{|c|c|c|c|c|}
\hline \multirow[t]{2}{*}{ Fertilizer Management } & \multicolumn{3}{|c|}{ Previous crops } & \multirow[t]{2}{*}{ Mean } \\
\hline & Potato & Garlic & Cauliflower & \\
\hline \multicolumn{5}{|l|}{2018} \\
\hline $\mathrm{F} 1$ & 11.3 & 10.5 & 10.2 & 10.7 \\
\hline F2 & 10.0 & 9.1 & 9.6 & 9.6 \\
\hline Mean & 10.6 & 9.8 & 9.9 & \\
\hline LSD $_{0.05}$ for Precrop & $2.45 \mathrm{NS}$ & & & \\
\hline $\operatorname{LSD}_{0.05}$ for Fertilizer & $2.0 \mathrm{NS}$ & & & \\
\hline LSD $_{0.05}$ for Precrop x Fertilizer & $4.47 \mathrm{NS}$ & & & \\
\hline CV\% & 23.0 & & & \\
\hline \multicolumn{5}{|l|}{2019} \\
\hline F1 & 11.8 & 11.0 & 10.4 & 11.1 \\
\hline $\mathrm{F} 2$ & 10.0 & 9.1 & 10.1 & 9.7 \\
\hline Mean & 11.0 & 10.1 & 10.2 & \\
\hline $\mathrm{LSD}_{0.05}$ for Precrop & $2.19 \mathrm{NS}$ & & & \\
\hline $\mathrm{LSD}_{0.05}$ for Fertilizer & $1.78 \mathrm{NS}$ & & & \\
\hline LSD $_{0.05}$ for Precrop x Fertilizer & $3.10 \mathrm{NS}$ & & & \\
\hline CV\% & 19.8 & & & \\
\hline
\end{tabular}



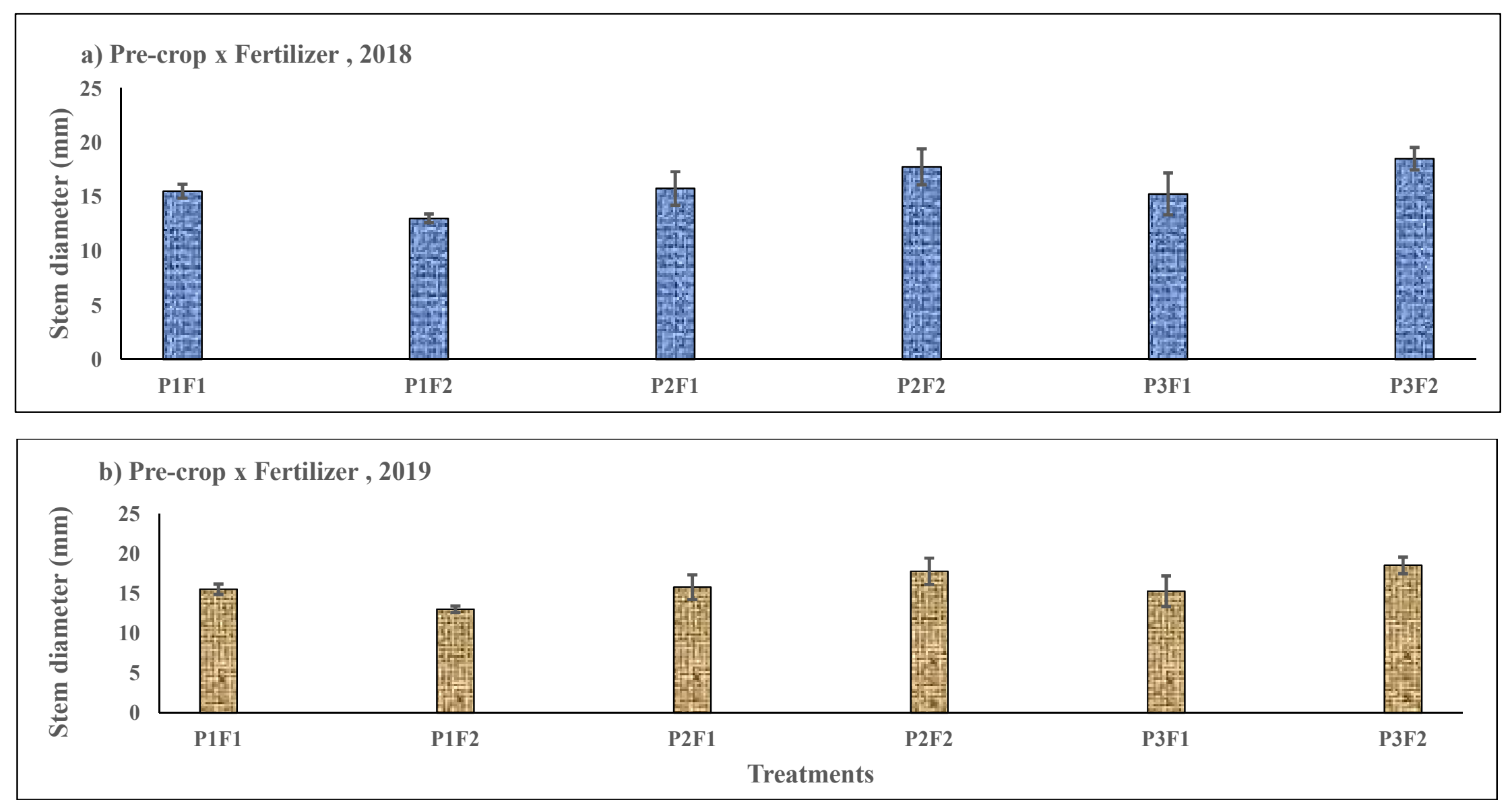

Fig. 3. Effect of the interaction of (a) Pre-crop x Fertilizer, 2018 and (b) Pre-crop x Fertilizer, 2019 on stem diameter of amaranth. Error bars represent standard error of the mean $(n=4)$. Same lower case letters indicate no significant differences between all treatments in each item $(P=0.05)$. P1: Potato; P2: Garlic; P3: Cauliflower; F1: Organic fertilizer; F2: Inorganic fertilizer 
a) Pre-crop x Fertilizer, 2018

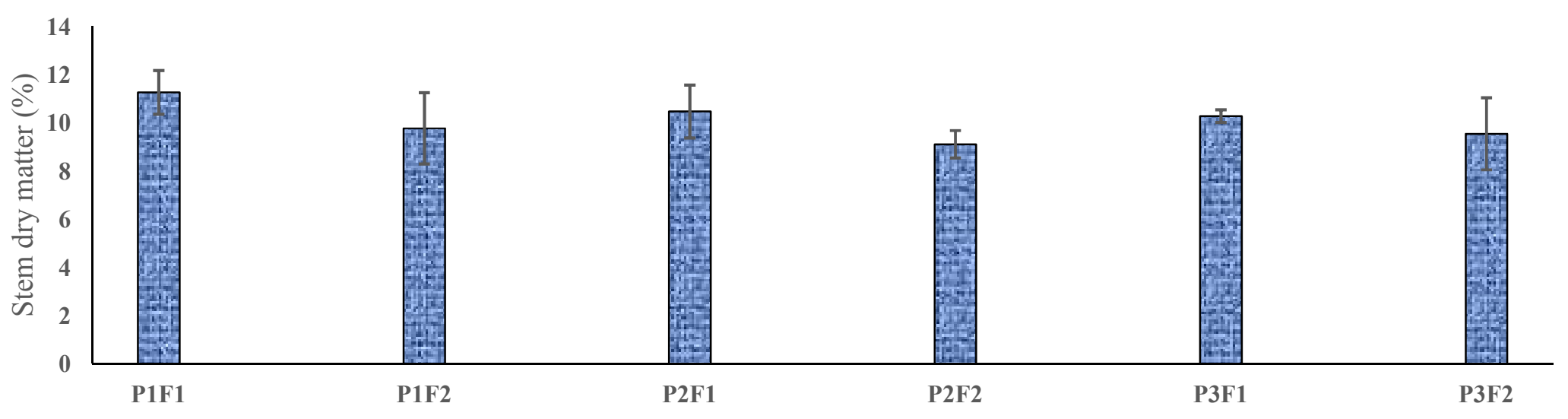

b) Pre-crop x Fertilizer, 2019

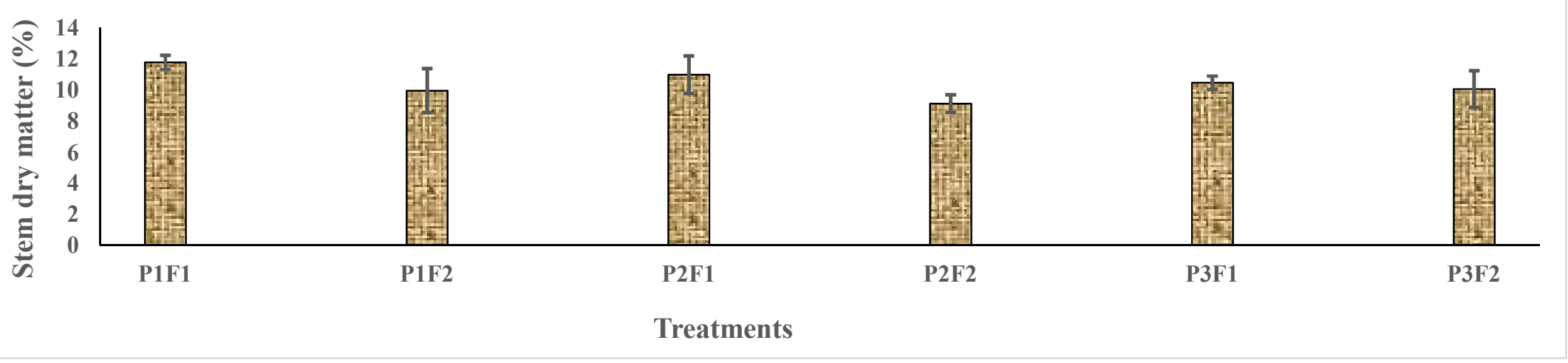

Fig. 4. Effect of the interaction of (a) Pre-crop $x$ Fertilizer, 2018 and (b) Pre-crop $x$ Fertilizer, 2019 on stem dry matter of amaranth. Error bars represent standard error of the mean $(n=4)$. Same lower case letters indicate no significant differences between all treatments in each item $(P=$ 0.05). P1: Potato; P2: Garlic; P3: Cauliflower; F1: Organic fertilizer; F2: Inorganic fertilizer 
a) Pre-crop $\mathrm{x}$ Fertilizer, 2018

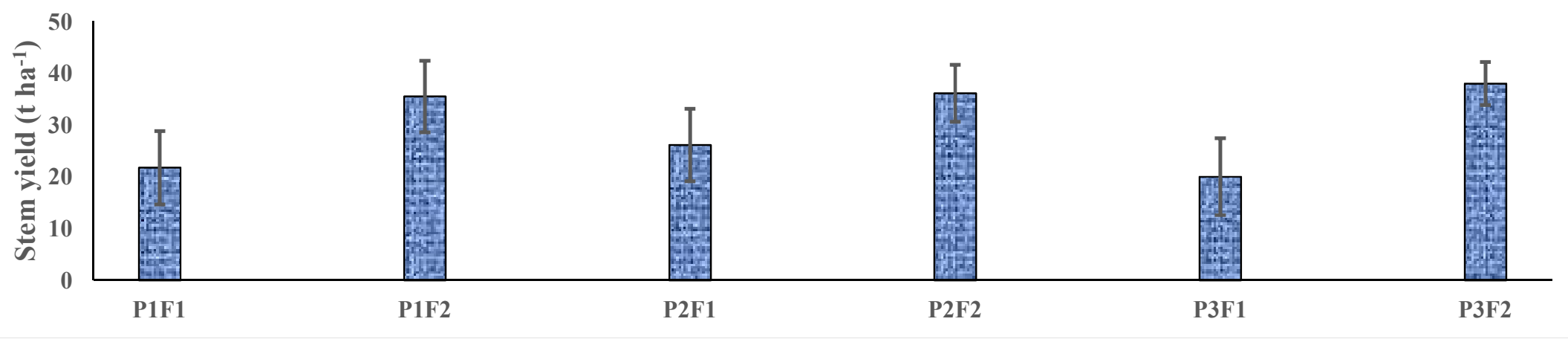

b) Pre-crop x Fertilizer, 2019

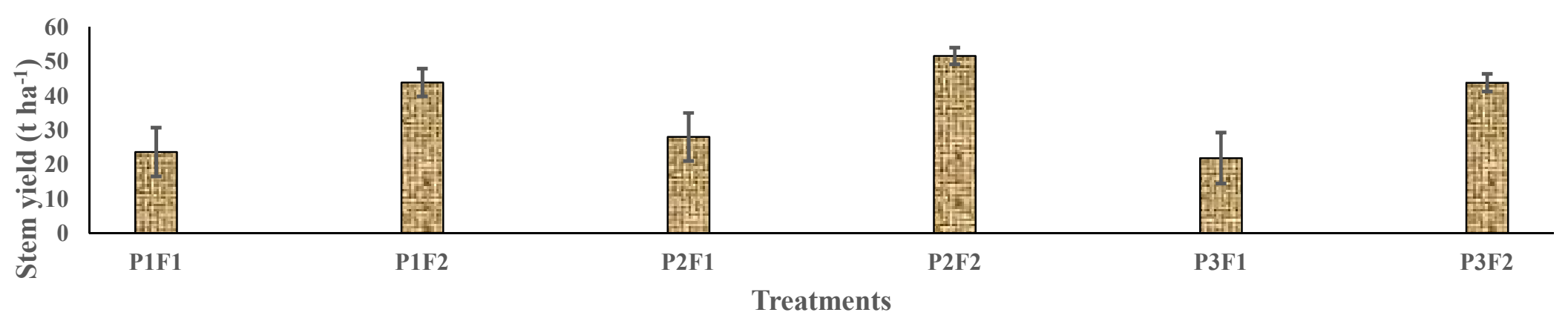

Fig. 5. Effect of the interaction of (a) Pre-crop x Fertilizer, 2018 and (b) Pre-crop x Fertilizer, 2019 on stem yield of amaranth. Error bars represent standard error of the mean $(n=4)$. Different lower case letters indicate significant differences between all treatments in each item $(P=0.05)$. P1:

Potato; P2: Garlic; P3: Cauliflower; F1: Organic fertilizer; F2: Inorganic fertilizer 
Table 9. Stem yield ( $\mathrm{t} \mathrm{ha}^{-1}$ ) of amaranth as affected by previous crops and fertilizers management under vegetables - vegetables - Rice cropping system during kharif-1, 2018 and 2019

\begin{tabular}{|c|c|c|c|c|}
\hline \multirow[t]{2}{*}{ Fertilizer Management } & \multicolumn{3}{|c|}{ Previous crops } & \multirow[t]{2}{*}{ Mean } \\
\hline & Potato & Garlic & Cauliflower & \\
\hline \multicolumn{5}{|l|}{2018} \\
\hline F1 & 21.8 & 26.1 & 20.0 & $22.6 \mathrm{~B}$ \\
\hline $\mathrm{F} 2$ & 35.5 & 36.1 & 38.0 & $36.5 \mathrm{~A}$ \\
\hline Mean & 28.6 & 31.1 & 29.0 & \\
\hline $\mathrm{LSD}_{0.05}$ for Precrop & $3.7^{*}$ & & & \\
\hline LSD $_{0.05}$ for Fertilizer & $3.0^{*}$ & & & \\
\hline LSD $_{0.05}$ for Precrop x Fertilizer & $5.2^{*}$ & & & \\
\hline $\mathrm{CV} \%$ & 26.0 & & & \\
\hline \multicolumn{5}{|l|}{2019} \\
\hline F1 & 24.0 & 28.0 & 22.0 & $24.4 \mathrm{~B}$ \\
\hline $\mathrm{F} 2$ & 44.0 & 51.4 & 44.0 & $46.2 \mathrm{~A}$ \\
\hline Mean & 33.6 & 39.6 & 32.7 & \\
\hline LSD $_{0.05}$ for Precrop & $3.7^{\star}$ & & & \\
\hline LSD $_{0.05}$ for Fertilizer & $2.9^{*}$ & & & \\
\hline LSD $_{0.05}$ for Precrop x Fertilizer & $5.2^{*}$ & & & \\
\hline CV\% & 24.6 & & & \\
\hline
\end{tabular}

\section{CONCLUSION}

From the above study it could be highlighted that previous crops had a positive impact on the yield parameters of stem amaranth like plant height in 2018 and leaf numbers of plant both in 2018 and 2019 Interaction effect of previous crops and fertilizers management exerted significant variations only on leaves per plant of amaranth both in 2018 and 2019. Whereas fertilizers management showed significant variation for plant height in 2019 and for stem yield both in 2018 and 2019.Proportionate distribution of rainfall and better availability of sunshine hours at growth and maturity stages of amaranth with fertilizers during the cropping season in general and more availability of nutrients under soil test based inorganic fertilizer management treatment achieved higher yield performance in 2019 than in 2018. Moreover, stem yield of amaranth was higher due to $\mathrm{N}$ based organic compost treated plots in 2019 compared to stem yield in 2018 under all the previous crops. But comparative results among all the three previous crops studied in the present investigation suggested that yield and yield parameters of stem amaranth were performed better when the pre-crop was garlic under Garlic - Amaranth - T. Aman cropping system due to soil test based inorganic fertilizer management and $\mathrm{N}$ based organic compost could be moderate yielding after previous crops.

\section{COMPETING INTERESTS}

Authors have declared that no competing interests exist.

\section{REFERENCES}

1. Teutonico RA, Knorr D. Amaranth composition, properties and application of a reddish covered food crop: Food technology.1985;39:49-61.

2. Nasim $M$, Shahidullah SM, Saha A, Muttaleb MA, Aditya TL, Ali MA, Kabir MS. Distribution of crops and cropping pattern in Bangladesh. Bangladesh Rice J. 2017; 21(2)1-55.

3. BBS (Bangladesh Bureau of Statistics). Bangladesh Statistics 2018. Statistics and Informatics Division, Ministry of Planning, GoB, Dhaka. 2019;323-324.

4. Karim MR, Hossain S, Rashid MA, Azad MAK, Jahan MAHS. Comparative advantage of vegetables. bangladesh $\mathrm{j}$. agril. res. 2011;36(1):87-95. 
5. Kumar B, Roy Sharma RP. Effect of Preceding Crops and Nitrogen Rates on Growth, Yield and Yield Attributes of Wheat. Indian Journal of Agricultural Research. 2000;34(1):34-38.

6. Mital KK. Vegetable production in the subtropics and tropics overseas, Technical Cooperation Agency Japan. 1975;25:146157.

7. Jeptoo A, Aguyoh JN, Saidi M. Improving Carrot Yield and Quality through the Use of Bio-Slurry Manure. Sustainable Agricultural Research. 2013;2(1):164-172.

8. Heitkamp F, Raupp J, Ludwig B. Soil organic matter pools and crop yields as affected by the rate of farmyard manure and use of biodynamic preparations in a sandy soil. Organic Agriculture. 2011;11: 111-124.

9. Premsekhar M, Rajashree V. Influence Organic Manures on Growth, Yield and Quality of Okra. American-Eurasian Journal of Sustainable Agriculture. 2009; 3(1):6-8.

10. Rahman SM E, Islam MA, Rahman MM, Oh DH. Effect of cattle slurry on growth, biomass yield and chemical composition of maize fodder. AsianAustralian Journal of Animal Science. 2008;2(1):1592-1598.

11. Mehdizadeh M, Dorbandi El, Naseri-Rad $H$, Tobeh A. Growth and yield of tomato (Lycopersicon esculentum Mill.) as influenced by different organic fertilizers. International Journal of Agronomy and Plant Production. 2013;4(4):734-738.

12. FRG (Fertilizer Recommendation Guide). Bangladesh Agricultural Research Council (BARC). Farmgate, Dhaka. 2012; 274.

13. Walkley, Black CV. An examination of the Degtjereff method for determining soil organic matter and a proposed modification for the chromic acid titration method. Soil Sci. 1934;37:29-38.

14. Michael P. Hydrogen-ion activity. In methods of soil analysis part 2 edited by $C$. A. Black. Amer. Soc. Agron., Inc. Publisher, USA. 1965;914-926.

15. Bremner JM, Mulvaney CS. Nitrogentotal. In Methods of Soil Analysis Part 2 edited by Page, Miller and Kenly. Amer. Soc. Agron, Inc. Publ., USA. 1982;595624.

16. Olsen SR, Cole CU, Watanable FS, Deun LA. Estimation of available $P$ in soil extraction with sodium bicarbonate. U. S. Agril. Cir.1954;929.

17. Knudsen D, Peterson GA, Pratt PF. Lithium, Sodium and Potassium. In methods of Soil Analysis Prt 2 edited by Page, Miller and Keenly. Amer. Soc. Agron, Inc. Publisher, USA. 1882;225245.

18. Williams $\mathrm{C} \mathrm{H}$, Steinbergs A. Soil sulphur fractions as chemical indices of available sulphur in some Australian soils: Aust. J. Agric. Res. 1959;10:340-352.

19. Gomez KA, Gomez AA. Statistical procedures for Agricultural Research. John Wiley and Sons Publication, New York. 1984;91-97.

20. Pang XP, Letey J. Organic farming: Challenge of timing nitrogen availability to crop nitrogen requirements. Soil Science Society of America Journal. 2000;64:247253.

21. Hartemink A, Buresh J, Bodegom PM, Braun AR, Jama $B$, Jansse $B H$. Inorganic Fertilizer nitrogen dynamics in fallows and maize on an Oxisol and Alfisol in the Highlands of Kenya. Geoderma. 2000;98:11-33.

22. Eghball B, Wienhold BJ, Gilley JE, Eigenberg RA. Mineralization of manure nutrients. Journal of Soil and Water Conservation. 2002;57(6):470-473.

23. Islam MM, Karim AJMS, Jahiruddin $M$, Majid MN, Miah MG, Mustaque AM, Hakim MA. Effects of organic manure and chemical fertilizers on crops in the RadishStem amaranth -Indian spinach cropping pattern in homestead area. Australian Journal of Crop Sciences. 2011;5(11): 1370-1378.

24. Hossain N, Islam M, Alamgir M, Kibria MG. Growth response of Indian Spinach to biogas plant residues. IOSR-Journal of Pharmacy and Biological Sciences. 2014; 9:1-6.

25. Olanrewaju OO. The effects of fertilizers on the growth and yield of Indian Spinach (Basella alba). University of Agriculture, Abeokuta, Ogun State, Nigeria. 2011; 2006:1607.

26. Akanbi KY. Response of fertilizers on yield of Amaranthus types in coastal Karnataka. Karnataka J. Agril. Sci. 2000;12(2):144148.

27. Stute JK, Posner JL. Synchrony between legume nitrogen release and corn demand 
in the upper Midwest. Agronomy Journal. 1995;87:1063-1069.

28. Onwonga R N, Lelei JJ, Freyer B, Friedel JK, Mwonga SM, Wandhawa P. Low Cost
Technologies for Enhancing $\mathrm{N}$ and $\mathrm{P}$ Availability and Maize (Zea mays L.) Performance on Acid Soils. World Journal of Agricultural Science. 2008;4(S):862-873.

(C) 2021 Pramanik et al.; This is an Open Access article distributed under the terms of the Creative Commons Attribution License (http://creativecommons.org/licenses/by/4.0), which permits unrestricted use, distribution, and reproduction in any medium, provided the original work is properly cited.

Peer-review history:

The peer review history for this paper can be accessed here: http://www.sdiarticle4.com/review-history/67482 